\title{
Sheffield

\section{Are all students 'hard to reach' in a digital higher education (H.E.) context?}

JONES-DEVITT, Stella, AUSTEN, Liz <http://orcid.org/0000-0002-2837-

8297>, IRWIN, Brian, MCDONALD, Kieran <http://orcid.org/0000-0001-65015439> and PARKIN, Helen

Available from Sheffield Hallam University Research Archive (SHURA) at: http://shura.shu.ac.uk/17106/

This document is the author deposited version. You are advised to consult the publisher's version if you wish to cite from it.

\section{Published version}

JONES-DEVITT, Stella, AUSTEN, Liz, IRWIN, Brian, MCDONALD, Kieran and PARKIN, Helen (2017). Are all students 'hard to reach' in a digital higher education (H.E.) context? The Journal of Educational Innovation, Partnership and Change, 3 (1), 147-158.

\section{Copyright and re-use policy}

See http://shura.shu.ac.uk/information.html 


\title{
Are all students 'hard to reach' in a digital higher education (HE) context?
}

\author{
Stella Jones-Devitt, Liz Austen, Brian Irwin, Kieran McDonald, Helen J. Parkin, Sheffield \\ Hallam University
}

\section{Contextualising digital inequalities}

The concept of 'hard to reach' groups in HE - and addressing such under-representation has been occupying Higher Education Institutions (HEIs) for many decades. The massification of HE started explicitly with the report by Robbins (1963), which called for mass expansion of $\mathrm{HE}$ in the UK, yet also recognised that certain steps had to be taken to encourage wider social mobility within the sector. This starting point spawned a range of national initiatives, such as Aimhigher and, recently, the National Collaborative Outreach Programme (NCOP) to try to engage the apparently 'unengaged', whilst access to HE including financial incentives - is now co-ordinated by an Office for Fair Access (OFFA); hence, it is now big business for all HEls.

The use of technology as part of the agenda to promote wider access by all has obfuscated a wider capability issue, with studies beginning to examine the intricacies of digital exclusion and questioning whether some students have 'the right kind of digital capital' (Seale et al, 2015). In seeking to avoid further digital inequalities, educators must acknowledge that there is evidence of a disparity in the relationship between transformative learning and technologyenabled learning (TEL). While highlighting that TEL has the potential to enhance and enrich student learning, Torrisi-Steele and Drew (2013), Henderson et al (2015) and Kirkwood (2014) all had reservations about its evident transformative nature. Evidence from our study indicates that the use of technology within HE can be primarily for efficiency and effectiveness - commonly known as hygiene factors - rather than for emancipation.

\section{Being a 'digital native' is not enough}

Anecdotally, there are strong beliefs held concerning assumptions that students arrive at HEls as apparent 'digital natives' who are very comfortable with all digital processes. However, whilst many students are attuned intuitively to being connected socially by using technology such as Facebook as part of their everyday lives, they are far less likely to arrive with effective information-retrieval and -interrogation approaches - as needed and expected of new entrant 'Generation Zs' for academic study or for future employability development. Evidence is beginning to suggest that the attributes of digital natives are poor predictors of competent information literacy (Sorgo et al, 2016). Our review found that students themselves often fail to appreciate the role of technology in student-centred approaches to learning, expressing support for logistical benefits and hygiene factors (Henderson et al, 2015; Torrisi-Steele and Drew, 2013) rather than for 'creative, collaborative, hyperconnected practices' (Henderson et al, 2015:10). This can be linked inherently with a student as consumer ethos (Henderson et al, 2015; Hutchings et al, 2014), in which metrics of satisfaction are aligned problematically with teaching practice. For example, measures of perceived 'usefulness' (Henderson et al, 2015) were used as proxies for effective TEL and, as noted, students tended to report preference for the logistical benefits offered by technology whilst saying little about how the technology enhanced or transformed their learning.

\section{Over-simplifying digital capacity}

We argue that this has led to an over-simplification of approaches to building authentic digital capacity within the student body, with hygiene factors and levels of participation being given primacy within technology-enhanced learning agendas. As noted by Comas Quinn 
(2011:228), this becomes the rapid development of ICT proficiency and digital skills rather than a robust examination of the 'pedagogical possibilities' of the chosen technology; hence, the default position of technology is to make things simpler for hard-pressed students by linking to efficiency of effort and - in doing so - to make learning more instrumental. This instrumental positioning of digital capability is also sold to staff as desirable, as, in adopting this ethos, both staff and students come to view technology as a way to minimise effort by acting in a performative, rather than pedagogically-led, manner. When students are placed at the centre of TEL, their voices - or imposed success measures - carry weight in any assessment of effectiveness.

Excellent student-centred teaching needs to assess tipping points when introducing new ways of learning, described by Hutchings et al, as the 'optimum disruption of the student experience' (2014:154); Beetham and Sharpe (2013:4) identify this as a disruption of norms to 'usher in completely new forms of learning activity'. Paradoxically, teaching which fails to appreciate this 'optimum disruption' when using technology is at risk of creating dissatisfied and unengaged students. As student satisfaction is now linked inherently to teaching excellence in UK HE (BIS, 2016), the negotiation of this balance requires a digitally-capable teacher: one who can juxtapose pedagogy with technological skills whilst removing the sovereignty - and consumption - of technological hygiene factors as an inevitable and desired rite of student passage.

\section{Developing engaged digitally-capable students}

In summary, evidence indicates that students are spending considerably less time studying (Endsleigh, 2015), yet their 'efficiency' savings are not being re-employed for learning purposes as many are substituting part-time working for studying in order to offset financial costs. This reinforces the notion of students as increasingly judicious consumers rather than as learners (Neves and Hillman, 2016). The pedagogical challenge concerns considering ways of engaging all students to understand how digital technology can position transformative learning 'within reach', whilst moving beyond technological hygiene and social connectedness. Our review concluded that a broader conceptualisation of digital capability is needed to promote teaching excellence in Higher Education. This might involve HEls in conceptualising a bolder consideration of the 'why' alongside the 'what' and the 'how'. Inclusion of an underlying pedagogy which cements the link between digital capability and teaching excellence can ground capability in an understanding of purpose and intended outcomes. This is a fundamental way to engage all students - and staff for that matter - to appreciate that risk-taking is an essential pre-requisite for developing their digital capability, rather than to rely on the quick-fix technological determinism that appears so prevalent at present; failure to do so arguably renders all students as 'hard to reach' in this context.

\section{Reference list}

Austen, L., Parkin, H. J., Jones-Devitt, S., McDonald, K. and Irwin, B. (2016) Digital capability and teaching excellence: an integrative review exploring what infrastructure and strategies are necessary to support effective use of technology enabled learning (TEL). Gloucester: QAA.

Beetham, H. and Sharpe, R. (2013) Rethinking pedagogy for a digital age: Designing for $21^{\text {st }}$ century learning. New York: Routledge.

Comas-Quinn, A. (2011) 'Learning to teach online or learning to become an online teacher: An exploration of teachers' experiences in a blended learning course.' ReCALL, 23(3), 218232. 
The Department of Business Innovation \& Skills [BIS] (2016) Success as a Knowledge Economy: Teaching Excellence, Social Mobility and Student Choice. Available at: https://www.gov.uk/government/publications/higher-education-success-as-a-knowledgeeconomy-white-paper (Accessed: 7 April 2017).

Endsleigh (2015) Student Survey. Available at: https://www.endsleigh.co.uk/pressreleases/10-august-2015/ (Accessed: 15 February 2017).

Henderson, M., Selwyn, N. and Aston, R. (2015) 'What works and why? Student perceptions of 'useful' digital technology in university teaching and learning.' Studies in Higher Education, 1(13).

Hutchings, M., Quinney, A. and Galvin, K. (2014) 'Negotiating the triple helix: Harnessing technology for transformation.' Proceedings of the International Conference on e-Learning, ICEL 2014, 76-85.

Kirkwood, A. (2014) 'Teaching and learning with technology in higher education: blended and distance education needs joined-up thinking rather than technological determinism.' Open Learning: The Journal of Open, Distance and e-Learning, 29(3), 206-221.

Neves, J. and Hillman, N. (2016) The 2016 Student Academic Experience Survey. The Higher Education Academy and Higher Education Policy Institute. Available at: http://www.hepi.ac.uk/wp-content/uploads/2016/06/Student-Academic-Experience-Survey2016.pdf (Accessed: 15 February 2017).

The Robbins Report (1963) Higher Education: Report of the Committee appointed by the Prime Minister under the Chairmanship of Lord Robbins. London: Her Majesty's Stationery Office.

Seale, J., Georgeson, J., Mamas, C. and Swain, J. (2015) 'Not the right kind of digital capital? An examination of the complex relationship between disabled students, their technologies and higher education institutions.' Computers \& Education, 82, 118-128.

Sorgo, A., Bartol, T., Dolnicar, D. and Boh Podgornik, B. (2016) 'Attributes of digital natives as predictors of information literacy in higher education.' British Journal of Educational Technology, DOI:10.1111/bjet.12451.

Torrisi-Steele, G and Drew, S. (2013) 'The literature landscape of blended learning in higher education: the need for better understanding of academic blended practice.' International Journal for Academic Development, 18(4), 371-383. 